\title{
Model Optimasi Pola Tanam Polikultur di Daerah Irigasi KAJAR 2C Kota Malang
}

\author{
Mentari Kinasih', Ruslan Wirosoedarmo², Bambang Suharto ${ }^{2}$ \\ ${ }^{1}$ Mahasiswa Program Magister Keteknikan Pertanian, Universitas Brawijaya, Jl. \\ Veteran, Malang 65145, email: mentari.kinasih@gmail.com \\ ${ }^{2}$ Fakultas Teknologi Pertanian, Universitas Brawijaya, Jl. Veteran, Malang 65145
}

\begin{abstract}
The 21.61 Ha of Irrigation area (IA) Kajar 2C is technical irrigation network located in Malang City. This research aims to develop the local commodity, there are rice, corn, cassava, and peanut. The Optimation method used linear programming by solver. The optimation cropping pattern scenario consists of 3 alternative, there are: (1) Rice/Rice/Rice; (2) Rice/Rice/Corn-Peanut; and (3) Cassava-Peanut/Cor/Corn. Every scenario is simulated by cropping patterns alternative by changing planting schedules existing from Oktober I, Oktober II, and Oktober III. Based on the results, the highest profits for each cropping pattern is X5 cropping pattern 7,203 Ha; X6 cropping pattern 10,78 Ha; and X8 cropping pattern 3,627 Ha. The maximum profit is Rp. 146.888.280. Keyword: cropping pattern, polyculture, linear programming, solver
\end{abstract}

\begin{abstract}
ABSTRAK
Daerah Irigasi Kajar (DI) Kajar 2C merupakan jaringan irigasi di Kota Malang dengan luas areal sawah $21,61 \mathrm{Ha}$. Penelitian ini bertujuan untuk memaksimalkan pendapatan petani dari jenis tanaman lokal yang biasa dikembangkan, yaitu padi dan palawija (jagung, ubi kayu, dan kacang tanah). Metode optimasi yang digunakan yaitu menggunakan program linier melalui model matematis dengan bantuan solver dari software Microsoft Excel. Skenario optimasi pola tanam terdiri dari 3 alternatif, yaitu: (1) Padi/Padi/Padi; (2) Padi/Padi/Jagung-Kacang Tanah; dan (3) Ubi Kayu-Kacang Tanah/Jagung/Jagung. Masing-masing alternatif pola tanam disimulasikan dengan awal tanam Oktober I, Oktober II, dan Oktober III. Berdasarkan hasil optimasi, keuntungan tertinggi diperoleh dengan menerapkan pola tanam polikultur X5 seluas $7,203 \mathrm{Ha}$; X6 seluas 10,78 Ha; dan X8 seluas 3,627 Ha. Total keuntungan maksimal yang diberikan adalah sebesar Rp. 146.888.280.
\end{abstract}

Kata kunci : pola tanam, polikultur, program linier, solver

\section{Pendahuluan}

Daerah Irigasi (DI) Kajar 2C merupakan salah satu jaringan irigasi yang menjadi kewenangan kota Malang berdasarkan Keputusan Menteri Pekerjaan Umum Nomor: 390/KPTS/M/2007. Berada di kelurahan Tunggulwulung, Kecamatan Lowokwaru, Kota Malang dan mempunyai luas areal sawah 21,61 Ha (Dinas PUPR Kota Malang, 2013). Keberadaan lahan pertanian di tengah kota mempunyai resiko besar mengalami konversi, yaitu alih fungsi lahan sawah menjadi fungsi hunian. Meningkatkan pendapatan petani kota Malang melalui optimasi pola tanam polikultur telah dilakukan juga oleh Mauidzotussyarifah et al. (2018) di Kota Batu yang menghasilkan produksi pertanian hortikultura buncis dan pakcoy mengalami peningkatan.

Kebutuhan air irigasi adalah jumlah air yang dibutuhkan oleh tanaman tertentu sesuai dengan jumlah air yang digunakan oleh tanaman untuk memenuhi kebutuhan perkolasi dan evapotranspirasi (penguapan). Kebutuhan air tanaman berbeda antara 
tanaman yang satu dengan yang lainnya tergantung dari jenis tanaman, hal ini dipengaruhi oleh nilai Koefisien Tanaman (Kc) (Wirosoedarmo, 2010). Kebutuhan air irigasi secara umum dapat diperoleh dari Curah Hujan $(\mathrm{CH})$, yaitu ketebalan hujan diukur oleh pencatat hujan (stasiun hujan) yang dianggap mewakili hujan di suatu kawasan dengan luasan tertentu. Lokasi penelitian ini cenderung berbukit, sehingga perhitungan distribusi hujan wilayah dilakukan dengan metode Polygon Thiessen (Harisuseno et al., 2017).

Pemodelan optimasi pola tanam polikultur merupakan penyusunan model yang disusun sesuai dengan kondisi lahan pertanian di Kota Malang yang terbatas dan keterbatasan sumber daya air dalam bentuk matematis untuk mencapai tujuan peningkatan keuntungan (profit). Pemodelan optimasi pola tanam dengan program linier dapat merencanakan dengan baik dengan cara mengoptimalkan jumlah sumber daya tersedia minimum seperti yang telah dilakukan oleh Mochammad et al. (2013), kendala ketersediaan air dapat diatasi dengan cara pemilihan jenis tanaman dan penentuan awal tanam yang tepat. Penyusunan model optimasi pola tanam polikultur menggunakan program linier terdiri dari 2 tahapan pembuatan fungsi linier, yaitu menentukan fungsi tujuan untuk memaksimumkan keuntungan dan merumuskan fungsi kendala ketersediaan air dan batasan ketersediaan lahan (Septyana et al., 2016).

\section{Bahan dan Metode}

\section{Lokasi Penelitian}

Penelitian ini dilaksanakan pada bulan Januari 2017 sampai dengan bulan Desember 2017 di Kota Malang yang berada pada koordinat $112^{\circ} 06^{\prime}-112^{\circ} 07^{\prime}$ Bujur Timur dan 7 $7^{\circ} 06^{\prime}-8^{\circ} 02^{\prime}$ Lintang Selatan seperti yang ditunjukkan oleh Gambar 1.

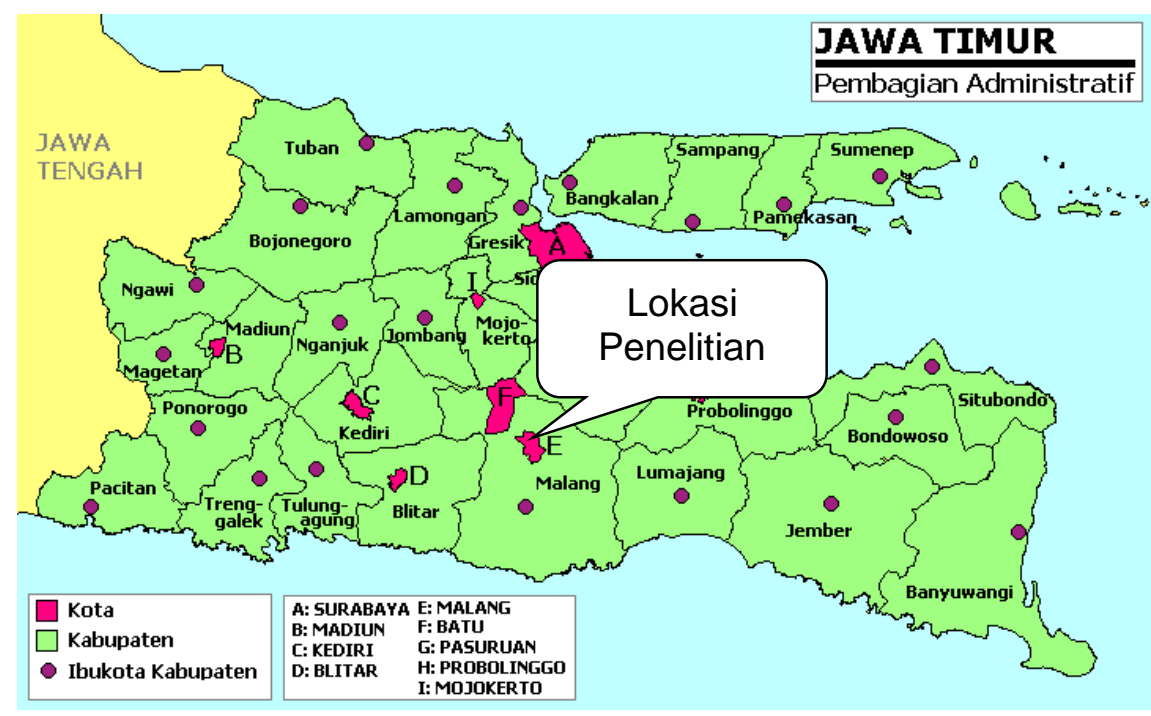

Gambar 1. Peta Lokasi Penelitian 


\section{Alat, Bahan, dan Metode}

Alat yang digunakan dalam penelitian ini yaitu SoftwareArcGIS 10.4.1. untuk membuat polygon thiessen. Software Cropwat 8.0 untuk menghitung ketersediaan air di lahan di lahan dan Program Solver Microsoft Excel untuk Optimasi Pola Tanam.

Bahan yang digunakan dalam penelitian ini yaitu Peta administrasi lokasi penelitian; Data iklim yang meliputi curah hujan, suhu, kelembapan, kecepatan angin, dan radiasi matahari tahun 2007 - 2016; Data curah hujan harian tahun 2007 - 2016; Data Debit Sungai Kajar tahun 2017; Data Pola Tanam Eksisting; dan Data Usaha Tani.

\section{Uji Konsistensi Data Curah hujan}

Uji konsistensi dilakukan untuk mengetahui besar pengaruh (konsistensi) data masing-masing stasiun hujan terhadap stasiun lainnya. Uji konsistensi data dilakukan dengan menggunakan analisa kurva massa ganda (double mass curve) yang menunjukkan hubungan kumulatif data hujan tahunan stasiun yang diuji $(\mathrm{X})$ dengan kumulatif data hujan stasiun lainnya sebagai pembanding $(\mathrm{Y})$ untuk mengetahui kelayakan data sebelum digunakan. Koefisien determinasi $\left(R^{2}\right)$ menunjukkan tingkat pengaruh data. $R^{2}$ bernilai antara $0-1$, yaitu semakin tinggi nilai menunjukkan konsistensi data yang tinggi (error rendah).

\section{Rata-Rata Curah Hujan Bulanan}

Rata-Rata Curah Hujan Bulanan dihitung dengan metode Polygon Thiessen seperti yang ditunjukkan oleh Persamaan 1.

$$
R_{i}=\frac{A_{1} R_{1}+A_{2} R_{2}+A_{3} R_{3}}{A_{1}+A_{2}+A_{3}}
$$

$R_{i}$ adalah curah hujan rata-rata bulan ke-i $(\mathrm{mm}), A_{1}$ luas cakupan wilayah stasiun hujan 1 bulan ke-i $\left(\mathrm{mm}^{2}\right)$, dan $R_{1}$ bulan ke-i adalah curah hujan di stasiun $1(\mathrm{~mm})$. Pembuatan poligon dilakukan dengan bantuan software ArcGIS 10.4.1.

\section{Perhitungan Curah Hujan Andalan}

Curah hujan andalan dihitung dengan menggunakan Metode Basic year dengan curah keandalan $80 \%\left(\mathrm{R}_{80}\right)$, yaitu $R_{80}=\frac{n}{5}+1$, dimana $n$ adalah jumlah data.

\section{Curah Hujan Efektif (Re)}

Curah hujan efektif yang dapat dimanfaatkan oleh tanaman secara langsung adalah $70 \%$ dari $\mathrm{R}_{80}$ untuk tanaman padi dan $50 \%$ dari $\mathrm{R}_{80}$ untuk tanaman palawija.

\section{Evapotranspirasi Potensial}

Perhitungan nilai evapotranspirasi potensial dilakukan dengan menggunakan Metode Penmann Monteith dari software Cropwat 8.0.

\section{Perumusan Pola Tanam}

Alternatif pola tanam yang digunakan dalam penelitian ini disusun dalam satu tahun Musim Hujan (MH)/Musim Kemarau I (MK I)/Musim Kemarau II (MK II) sebagai berikut: 
Pola Tanam $1\left(X_{1}\right)$ : Padi/Padi/Padi (Awal Tanam Oktober I);

Pola Tanam $2\left(X_{2}\right)$ : Padi/Padi/Padi (Awal Tanam Oktober II);

Pola Tanam $3\left(X_{3}\right)$ : Padi/Padi/Padi (Awal Tanam Oktober III);

Pola Tanam $4\left(X_{4}\right)$ : Padi/Padi/Jagung-Kacang Tanah (Awal Tanam Oktober I);

Pola Tanam $5\left(X_{5}\right)$ : Padi/Padi/Jagung-Kacang Tanah (Awal Tanam Oktober II);

Pola Tanam $6\left(X_{6}\right)$ : Padi/Padi/Jagung-Kacang Tanah (Awal Tanam Oktober III);

Pola Tanam $7\left(X_{7}\right)$ : Ubi Kayu-Kacang Tanah/Jagung/Jagung (Awal Tanam Oktober I);

Pola Tanam $8\left(X_{8}\right)$ : Ubi Kayu-Kacang Tanah/Jagung/Jagung (Awal Tanam Oktober II)

Pola Tanam $9\left(X_{9}\right)$ : Ubi Kayu-Kacang Tanah/Jagung/Jagung (Awal Tanam Oktober III).

\section{Perhitungan Kebutuhan Air}

Kebutuhan air irigasi untuk jenis tanaman padi dan palawija tidak sama. Kebutuhan air total di sawah untuk tanaman padi ditunjukkan oleh Persamaan 2.

$$
N F R=E T_{c}+P+W L R-R e
$$

NFR (Netto Field Water Requirement) adalah kebutuhan air bersih di sawah $(\mathrm{mm} / \mathrm{hari})$; $E T_{c}$ adalah kebutuhan air konsumtif tanaman $(\mathrm{mm} / \mathrm{hari}) ; P$ adalah perkolasi $(\mathrm{mm} / \mathrm{hari})$; $W L R$ adalah penggantian lapisan air $(\mathrm{mm} / \mathrm{hari})$; dan $R e$ adalah curah hujan efektif $(\mathrm{mm} /$ hari $)$.

$$
E T_{c}=E T_{o} \times K_{c}
$$

$E T_{c}$ adalah kebutuhan air konsumtif tanmaan $(\mathrm{mm} / \mathrm{hari}) ; E T_{o}$ adalah evapotranspirasi potensial $(\mathrm{mm} / \mathrm{hari}) ; K_{c}$ adalah koefisien tanaman.

\section{Debit Andalan}

Debit saluran irigasi Kajar 2C $(Q)$ dihitung dengan menggunakan Rumus Manning: $Q=A \times \frac{1}{n}\left(R^{2 / 3}\right)\left(S^{1 / 2}\right)$, koefisien Manning $(n)$ saluran batu disemen adalah sebesar $n=$ 0.025 (Purnomo, 2013). Dimensi saluran ditunjukkan oleh Gambar 2.

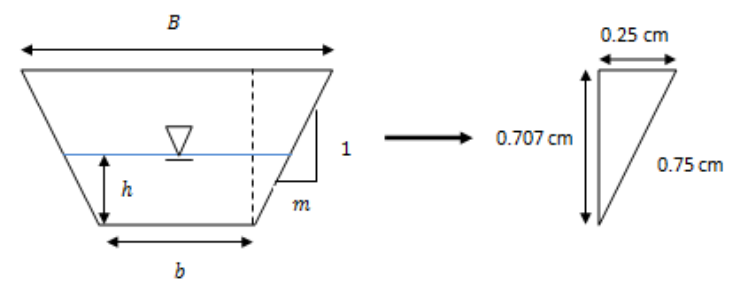

Gambar 2. Dimensi Saluran Irigasi Kajar 2C

Kemiringan Dasar Saluran $(S$ ) ditentukan menggunakan elevasi (yang diketahui dari Aplikasi Google Earth) pada bulan Maret (2017), titik tertinggi saluran berada pada koordinat $7^{\circ} 55^{\prime}$ LS dan $112^{\circ} 36^{\prime}$ BT yaitu $t_{1}=539 \mathrm{~m}$ dan titik terendah saluran pada 
koordinat $7^{\circ} 55^{\prime}$ LS dan $112^{\circ} 37^{\prime}$ BT yaitu $t_{2}=522 \mathrm{~m}$; dan panjang saluran irigasi D.I. Kajar 2C yaitu $l=1420 \mathrm{~m}$.

\section{Analisis Model Matematika}

Penelitian ini menganalisis pemecahan dasar dalam program linier untuk mencari kombinasi terbaik dari keterbatasan sumber daya air hingga diperoleh keuntungan terbesar. Fungsi tujuan yang iingi dicapai dalam penelitian ini ditunjukkan oleh Persamaan 4.

$$
Z=\sum_{i=1}^{n} C_{i} X_{i}
$$

$Z$ adalah keuntungan maksimum $(R p), C_{i}$ adalah keuntungan pola tanam ke-i $(\mathrm{Rp} / \mathrm{Ha})$, dan $X_{i}$ adalah luas tanam optimal untuk pola tanam ke-i.

Optimasi dilakukan dengan menggunakan bantuan program Solver dari Microsoft Excel.

\section{Hasil dan Pembahasan}

\section{Uji Konsistensi Data Curah hujan}

Terdapat 3 stasiun hujan di Kota Malang seperti yang ditunjukkan oleh Tabel 1.

Tabel 1. Profil Stasiun Hujan Kota Malang

\begin{tabular}{lrrr}
\hline \multirow{2}{*}{ Nama Stasiun } & Pos & \multicolumn{2}{c}{ Letak Koordinat } \\
\cline { 3 - 4 } & & $\begin{array}{c}\text { Lintang } \\
\text { Selatan }\end{array}$ & $\begin{array}{c}\text { Bujur } \\
\text { Timur }\end{array}$ \\
\hline Blimbing & 53 & $07^{\circ} 57^{\prime} 08^{\prime \prime}$ & $112^{\circ} 38^{\prime} 33.9^{\prime \prime}$ \\
Sukun & 52 & $07^{\circ} 59^{\prime} 39^{\prime \prime}$ & $112^{\circ} 37^{\prime} 18^{\prime \prime}$ \\
Kedungkandang & 51 & $07^{\circ} 59^{\prime} 35^{\prime \prime}$ & $112^{\circ} 39^{\prime 2} 0^{\prime \prime}$ \\
\hline \multicolumn{2}{l}{ Sumber: PSAWS Bango-Gedangan Malang (2017) }
\end{tabular}

Hasil Uji konsistensi menunjukkan bahwa pengaruh data curah hujan di Stasiun Blimbing dengan dua Stasiun hujan lainnya sangat kuat yaitu sebesar $99.6 \%$ seperti yang ditunjukkan oleh Gambar 3.

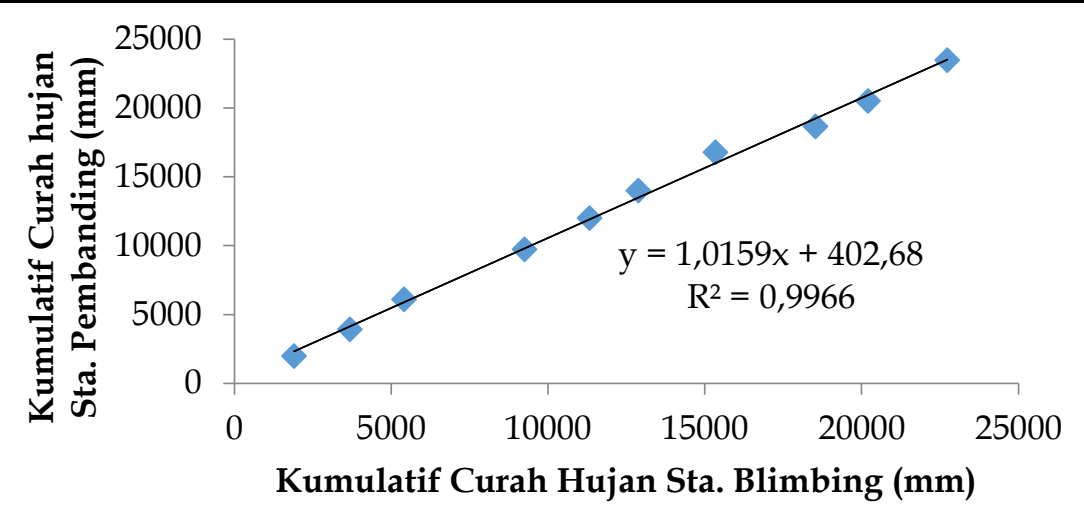

Gambar 3. Hubungan Kumulatif Hujan Tahunan Stasiun Blimbing dengan Stasiun Sukun dan Stasiun Kedungkandang

Pengaruh data curah hujan di Stasiun Sukun dengan dua Stasiun hujan lainnya sangat kuat yaitu sebesar $99.7 \%$ seperti yang ditunjukkan oleh Gambar 4 . 


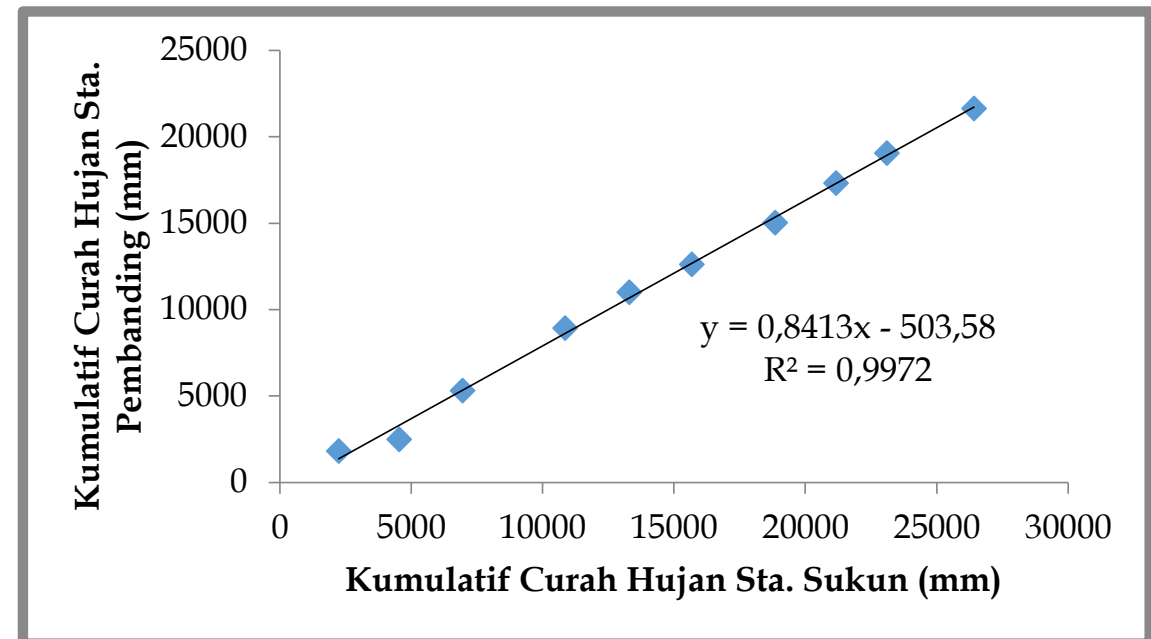

Gambar 4. Hubungan Kumulatif Hujan Tahunan Sukun dengan Stasiun Kedungkandang dan Stasiun Blimbing

Pengaruh data curah hujan di Stasiun Kedungkandang dengan dua Stasiun hujan lainnya sangat kuat yaitu sebesar $99.8 \%$ seperti yang ditunjukkan oleh Gambar 5 .

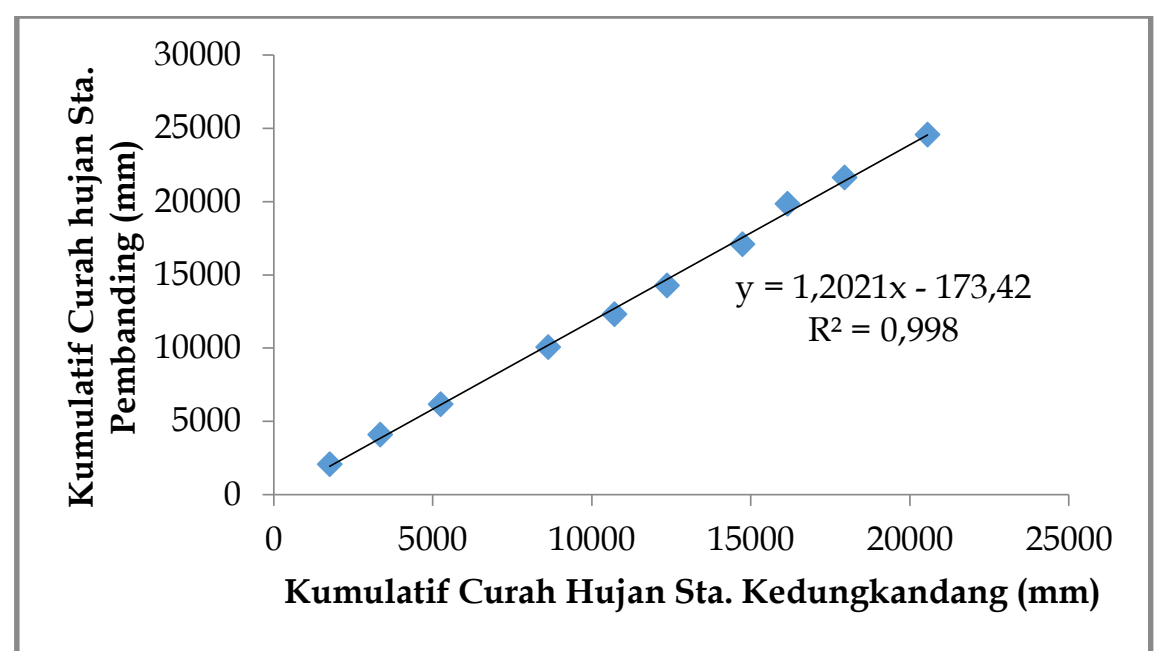

Gambar 5. Hubungan Kumulatif Hujan Tahunan Stasiun Kedungkandang dengan Stasiun Blimbing dan Stasiun Sukun

Berdasarkan uji konsistensi yang telah dilakukan pada masing-masing stasiun hujan diperoleh hasil bahwa data hujan dari ketiga stasiun ini layak untuk digunakan yang ditunjukkan oleh nilai kesalahan yang sangat kecil yaitu berkisar antara $0.2 \%-0.4 \%$.

\section{Rata-Rata Curah Hujan Bulanan}

Berdasarkan luas wilayah masing-masing poligon, Stasiun Kedungkandang merupakan stasiun hujan yang memiliki cakupan wilayah yang paling luas seperti yang ditunjukkan oleh Gambar 6. 


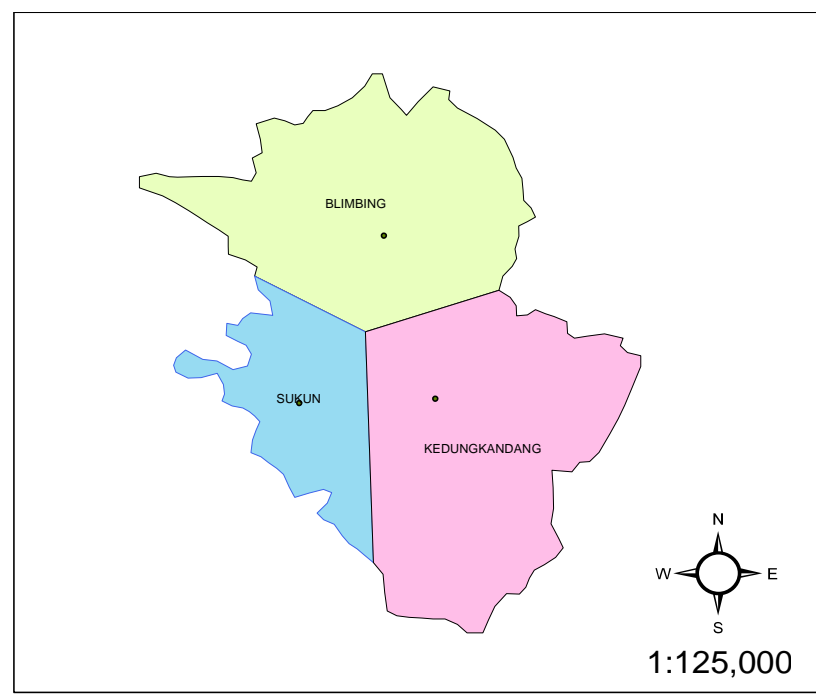

Gambar 6. Hasil Polygon Thiessen Tiga Stasiun Hujan di Kota Malang

Poligon 1 merupakan daerah yang terwakili oleh Stasiun hujan Sukun, yaitu seluas 192.25 Ha. Poligon 2 adalah daerah yang terwakili oleh Stasiun Blimbing dengan luas cakupan wilayah sebesar $442.25 \mathrm{Ha}$. Poligon 3 adalah daerah yang terwakili oleh Stasiun Kedungkandang dengan cakupan wilayah seluas $493.75 \mathrm{Ha}$.

Data curah hujan rerata 3 (tiga) stasiun hujan tahun 2007 - 2016 seperti yang ditunjukkan oleh Tabel 2.

Tabel 2. Curah hujan Bulanan Rerata 3 (tiga) Stasiun tahun 2007 - 2016

\begin{tabular}{|c|c|c|c|c|c|c|c|c|c|c|c|c|c|}
\hline \multirow[t]{2}{*}{ Tahun } & \multicolumn{12}{|c|}{ Curah Hujan (mm) } & \multirow[t]{2}{*}{$\begin{array}{c}\text { Jumlah } \\
\text { (mm) }\end{array}$} \\
\hline & Jan & Feb & Mar & Apr & Mei & Jun & Jul & Agt & Sep & Okt & Nop & Des & \\
\hline 2007 & 55.40 & 283.83 & 393.99 & 363.59 & 56.57 & 32.14 & 8.05 & 8.25 & 0 & 9.58 & 196.85 & 493.77 & 1902.02 \\
\hline 2008 & 289.74 & 239.35 & 439.32 & 130.92 & 66.17 & 40.21 & 0 & 2.62 & 26.02 & 88.19 & 193.71 & 308.22 & 1824.47 \\
\hline 2009 & 397.27 & 448.56 & 205.53 & 206.18 & 163.47 & 31.67 & 6.35 & 2.95 & 1.22 & 47.22 & 186.55 & 126.85 & 1823.82 \\
\hline 2010 & 466.36 & 453.44 & 361.62 & 426.81 & 275.16 & 76.37 & 107.12 & 152.03 & 310.22 & 183.05 & 476.55 & 363.13 & 3651.86 \\
\hline 2011 & 282.40 & 178.85 & 368.45 & 301.13 & 228.03 & 9.21 & 0 & 0 & 0.87 & 58.12 & 424.89 & 285.84 & 2137.79 \\
\hline 2012 & 309.58 & 272.31 & 219.26 & 123.06 & 35.88 & 4.30 & 0.87 & 0 & 0 & 90.72 & 178.73 & 503.10 & 1737.81 \\
\hline 2013 & 321.64 & 426.11 & 262.11 & 271.31 & 178.67 & 245.92 & 98.34 & 0 & 0 & 33.68 & 225.31 & 481.31 & 2544.4 \\
\hline 2014 & 251.72 & 186.19 & 279.05 & 450.38 & 218.86 & 43.52 & 201.86 & 7.09 & 0 & 7.55 & 249.57 & 372.12 & 2267.91 \\
\hline 2015 & 145.59 & 242.25 & 358.33 & 331.26 & 158.08 & 10.59 & 0 & 0.44 & 0 & 9.16 & 96.27 & 420.52 & 1772.49 \\
\hline 2016 & 132.82 & 554.85 & 381.67 & 166.92 & 186.39 & 208.53 & 61.33 & 91.44 & 61.04 & 157.40 & 518.94 & 180.94 & 2702.27 \\
\hline Rerata & 265.25 & 328.57 & 326.93 & 277.16 & 156.73 & 70.25 & 48.39 & 26.48 & 39.94 & 68.47 & 274.74 & 353.58 & 2236.48 \\
\hline
\end{tabular}

Sumber: Hasil Perhitungan (2017)

\section{Curah Hujan Andalan}

Hasil perhitungan curah hujan andalan $\left(\mathrm{R}_{80}\right)$ ditunjukkan oleh Tabel 3.

Tabel 3. Perhitungan Curah Hujan Andalan

\begin{tabular}{|c|c|c|c|c|c|c|}
\hline \multicolumn{3}{|c|}{ Data Hujan } & \multicolumn{3}{|c|}{ Rangking Hujan } & \multirow[b]{2}{*}{ Ket } \\
\hline No & Tahun & $\begin{array}{c}\mathrm{CH} \\
(\mathrm{mm})\end{array}$ & No & Tahun & $\begin{array}{c}\mathrm{CH} \\
(\mathrm{mm})\end{array}$ & \\
\hline 1 & 2007 & 1899.95 & 1 & 2012 & 1735.54 & \\
\hline 2 & 2008 & 1822.85 & 2 & 2015 & 1783.67 & \\
\hline 3 & 2009 & 1922.12 & 3 & 2008 & 1822.85 & $\mathrm{R}_{80}$ \\
\hline 4 & 2010 & 3650.89 & 4 & 2007 & 1899.95 & \\
\hline 5 & 2011 & 2139.88 & 5 & 2009 & 1922.12 & \\
\hline 6 & 2012 & 1735.54 & 6 & 2011 & 2139.88 & \\
\hline 7 & 2013 & 2542.19 & 7 & 2014 & 2311.27 & \\
\hline 8 & 2014 & 2311.27 & 8 & 2013 & 2542.19 & \\
\hline 9 & 2015 & 1783.67 & 9 & 2016 & 2700.18 & \\
\hline 10 & 2016 & 2700.18 & 10 & 2010 & 3650.89 & \\
\hline
\end{tabular}




\section{Curah Hujan Efektif (Re)}

Hasil perhitungan Re periode 10 harian disajikan dalam Tabel 4.

Tabel 4. Perhitungan Curah Hujan Efektif

\begin{tabular}{|c|c|c|c|c|c|c|}
\hline \multirow{2}{*}{\multicolumn{2}{|c|}{ Periode }} & \multicolumn{3}{|c|}{$\mathbf{R}_{\text {ef }}$ Padi } & \multicolumn{2}{|c|}{$R_{\text {ef }}$ Palawija } \\
\hline & & \multirow{2}{*}{$\begin{array}{r}\mathbf{R}_{\mathbf{8 0}}(\mathbf{m m}) \\
91.42\end{array}$} & $\begin{array}{c}R_{80}{ }^{*} 0.7 \\
(\mathrm{~mm})\end{array}$ & mm hari-1 & $\begin{array}{c}R_{80}{ }^{*} 0.5 \\
(\mathrm{~mm})\end{array}$ & $\mathrm{mm}$ hari-1 $^{-1}$ \\
\hline \multirow{3}{*}{ Okt } & 1 & & 63.99 & 6.40 & 45.71 & 4.57 \\
\hline & II & 15.52 & 10.86 & 1.09 & 7.76 & 0.78 \\
\hline & III & 182.66 & 127.86 & 11.62 & 91.33 & 8.30 \\
\hline \multirow{3}{*}{ Nop } & I & 106.00 & 74.20 & 7.42 & 53 & 5.30 \\
\hline & II & 21.46 & 15.02 & 1.50 & 10.73 & 1.07 \\
\hline & III & 111.68 & 78.18 & 7.82 & 55.84 & 5.58 \\
\hline \multirow{3}{*}{ Des } & 1 & 123.31 & 86.32 & 8.63 & 61.655 & 6.17 \\
\hline & II & 89.53 & 62.67 & 6.27 & 44.765 & 4.48 \\
\hline & III & 225.96 & 158.17 & 14.38 & 112.98 & 10.27 \\
\hline \multirow{3}{*}{ Jan } & 1 & 69.53 & 48.67 & 4.87 & 34.765 & 3.48 \\
\hline & II & 46.49 & 32.54 & 3.25 & 23.245 & 2.32 \\
\hline & III & 15.03 & 10.52 & 0.96 & 7.515 & 0.68 \\
\hline \multirow{3}{*}{ Feb } & 1 & 62.52 & 43.76 & 4.38 & 31.26 & 3.13 \\
\hline & II & 1.31 & 0.92 & 0.09 & 0.655 & 0.07 \\
\hline & III & 2.35 & 1.65 & 0.18 & 1.175 & 0.13 \\
\hline \multirow{3}{*}{ Mar } & 1 & 3.89 & 2.72 & 0.27 & 1.945 & 0.19 \\
\hline & II & 36.29 & 25.40 & 2.54 & 18.145 & 1.81 \\
\hline & III & 0 & 0 & 0 & 0 & 0 \\
\hline \multirow{3}{*}{ Apr } & 1 & 0 & 0 & 0 & 0 & 0 \\
\hline & II & 0 & 0 & 0 & 0 & 0 \\
\hline & III & 0 & 0 & 0 & 0 & 0 \\
\hline \multirow{3}{*}{ Mei } & 1 & 0 & 0 & 0 & 0 & 0 \\
\hline & II & 2.63 & 1.84 & 0.18 & 1.315 & 0.13 \\
\hline & III & 0 & 0 & 0 & 0 & 0 \\
\hline \multirow{3}{*}{ Jun } & 1 & 25.97 & 18.18 & 1.82 & 12.985 & 1.30 \\
\hline & II & 0 & 0 & 0 & 0 & 0 \\
\hline & III & 0 & 0 & 0 & 0 & 0 \\
\hline \multirow{3}{*}{ Jul } & 1 & 24.15 & 16.91 & 1.69 & 12.075 & 1.21 \\
\hline & II & 7.25 & 5.08 & 0.51 & 3.625 & 0.36 \\
\hline & III & 56.19 & 39.33 & 3.58 & 28.095 & 2.55 \\
\hline \multirow{3}{*}{ Agt } & 1 & 66.76 & 46.73 & 4.67 & 33.38 & 3.34 \\
\hline & II & 54.31 & 38.02 & 3.80 & 27.155 & 2.72 \\
\hline & III & 72.25 & 50.58 & 4.60 & 36.125 & 3.28 \\
\hline \multirow{3}{*}{ Sep } & 1 & 138.69 & 97.08 & 9.71 & 69.345 & 6.93 \\
\hline & II & 122.30 & 85.61 & 8.56 & 61.15 & 6.12 \\
\hline & III & 47.40 & 33.18 & 3.32 & 23.7 & 2.37 \\
\hline
\end{tabular}

Hasil perhitungan menunjukkan tidak tersedianya air hujan pada bulan Maret III hingga bulan Mei I serta pada bulan Juni yang menjelaskan bahwa pada bulan-bulan tersebut merupakan puncak Musim Kemarau di Kota Malang.

\section{Evapotranspirasi Potensial}

Hasil perhitungan evapotranspirasi potensial (ETo) ditunjukkan oleh Tabel 5.

Tabel 5. Hasil Perhitungan Evapotranspirasi Potensial

\begin{tabular}{ccccccc}
\hline ETo & \multicolumn{6}{c}{ Bulan } \\
\hline \multirow{3}{*}{ mm hari $^{-1}$} & Okt & Nop & Des & Jan & Feb & Mar \\
\cline { 2 - 7 } & 4.39 & 3.62 & 2.88 & 3.01 & 3.16 & 3.42 \\
\cline { 2 - 7 } & Apr & Mei & Jun & Jul & Agt & Sep \\
\cline { 2 - 7 } & 3.66 & 3.90 & 3.93 & 3.93 & 4.08 & 4.36 \\
\hline Sumber: Hasil Perhitungan (2017) & & &
\end{tabular}

Nilai ETo paling rendah terjadi pada bulan Desember (mendekati akhir musim hujan), kemudian naik perlahan hingga yang tertinggi terjadi pada bulan Oktober 
(sepanjang musim kemarau), dan mulai turun lagi bulan Nopember (memasuki musim hujan). Intensitas penyinaran matahari yang tinggi menyebabkan suhu udara tinggi dan kelembapan menjadi rendah, sehingga penguapan semakin tinggi.

\section{Kebutuhan Air Irigasi}

Kebutuhan Air Irigasi untuk Pola Tanam Polikultur dihitung berdasarkan total kebutuhan air konsumtif (ETc) tiap jenis tanaman dalam satu lahan sesuai dengan porsi tumpangsarinya. Tumpangsari tanaman Jagung dan Kacang Tanah ditunjukkan oleh Gambar 7.

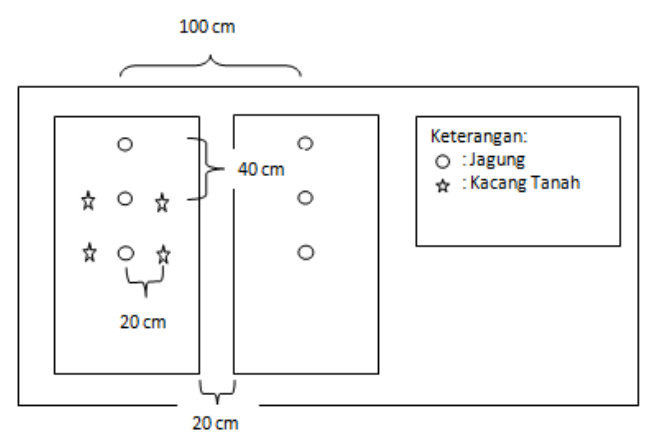

Gambar 7. Tumpangsari Jagung dan Kacang Tanah

Jagung dan Kacang Tanah disusun sedemikian sehingga dalam satu guludan (80 $\mathrm{cm}$ ) terdapat satu baris tanaman Jagung dengan jarak tanam $40 \mathrm{~cm}$, sehingga dalam $1 \mathrm{Ha}$ lahan terdapat populasi tanaman Jagung sejumlah 25,000 tanaman (100\%), sedangkan tanaman Kacang Tanah ditanam dengan jarak $20 \mathrm{~cm}$ dari tanaman jagung dan $40 \mathrm{~cm}$ antar tanaman kacang tanah (dalam satu guludan) sehingga dalam $1 \mathrm{Ha}$ lahan terdapat populasi tanaman Kacang Tanah sebesar 50,000 tanaman (40\%).

Tumpangsari tanaman Ubi kayu dan Kacang Tanah ditunjukkan oleh Gambar 8.

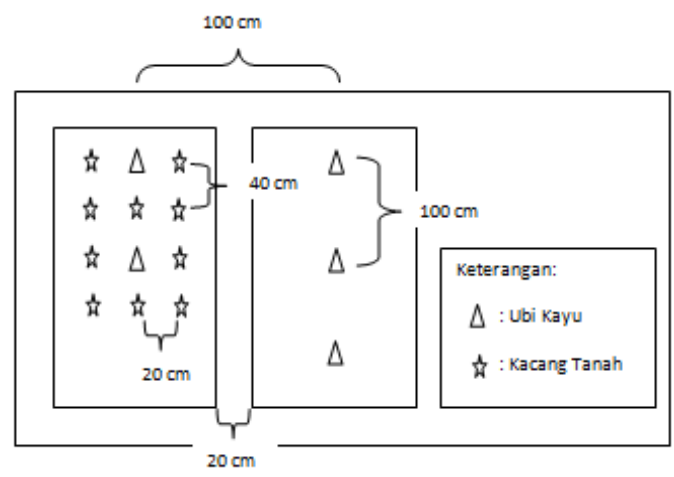

Gambar 8. Tumpangsari Ubi Kayu dan Kacang Tanah

Berdasarkan gambar tersebut dalam $1 \mathrm{Ha}$ lahan terdapat populasi tanaman Ubi Kayu sebanyak 10,000 (100\%). Tanaman Kacang Tanah ditanam di sela tanaman Ubi Kayu dengan jarak antar baris dalam 1 guludan adalah $40 \mathrm{~cm}$, sehingga dalam $1 \mathrm{Ha}$ lahan Ubi 
Kayu terdapat populasi tanaman Kacang Tanah sejumlah 62,500 tanaman (50\%). Tumpangsari tanaman Jagung dengan Ubi kayu ditunjukkan oleh Gambar 9.

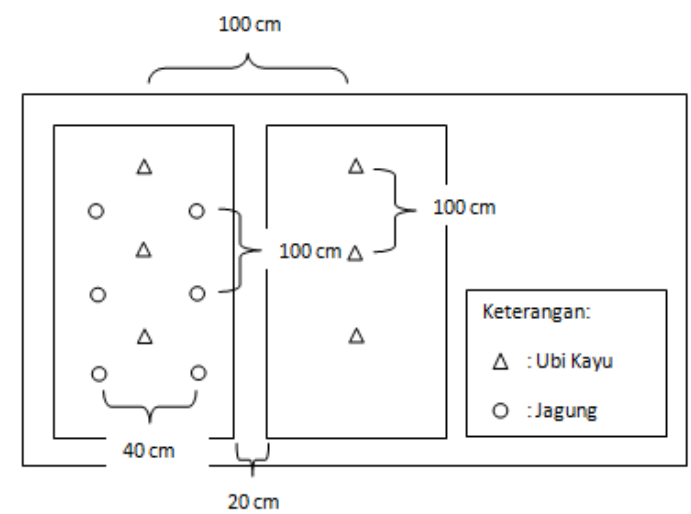

Gambar 9. Tumpangsari Ubi Kayu dan Jagung

Berdasarkan jarak tanam yang telah disusun, populasi tanaman Jagung dalam satu guludan (lebar $80 \mathrm{~cm}$ ) terdapat 20,000 tanaman Jagung (80\%).

\section{Kebutuhan Air Penyiapan lahan}

Kebutuhan Air Penyiapan Lahan atau Land Preparation (LP) dibutuhkan oleh tanaman padi sebelum memasuki masa tanam. Kebutuhan air penyiapan lahan untuk tanaman padi ditunjukkan oleh Gambar 10.

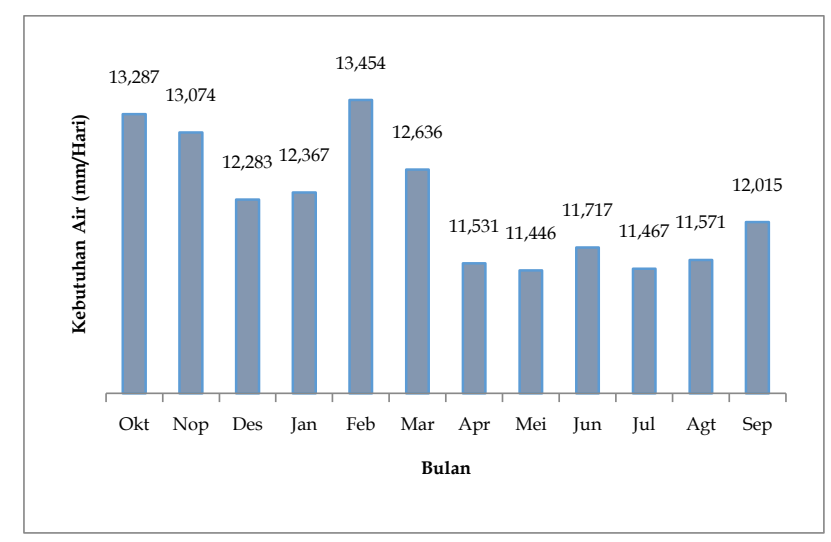

Gambar 10. Kebutuhan Air untuk Penyiapan Lahan

Penggantian lapisan air diperlukan selama 30 hari ( 3 periode) awal setelah tanaman padi ditanam. Tinggi genangan air yang diperlukan sebesar $50 \mathrm{~mm}$, sehingga kebutuhan air untuk penggantian lapisan air sebesar $1.667 \mathrm{~mm} / \mathrm{hari}$.

\section{Debit Andalan}

Hasil perhitungan Debit Andalan $\left(Q_{80}\right)$ saluran irigasi Daerah Irigasi Kajar 2C ditunjukkan oleh Tabel 8. 


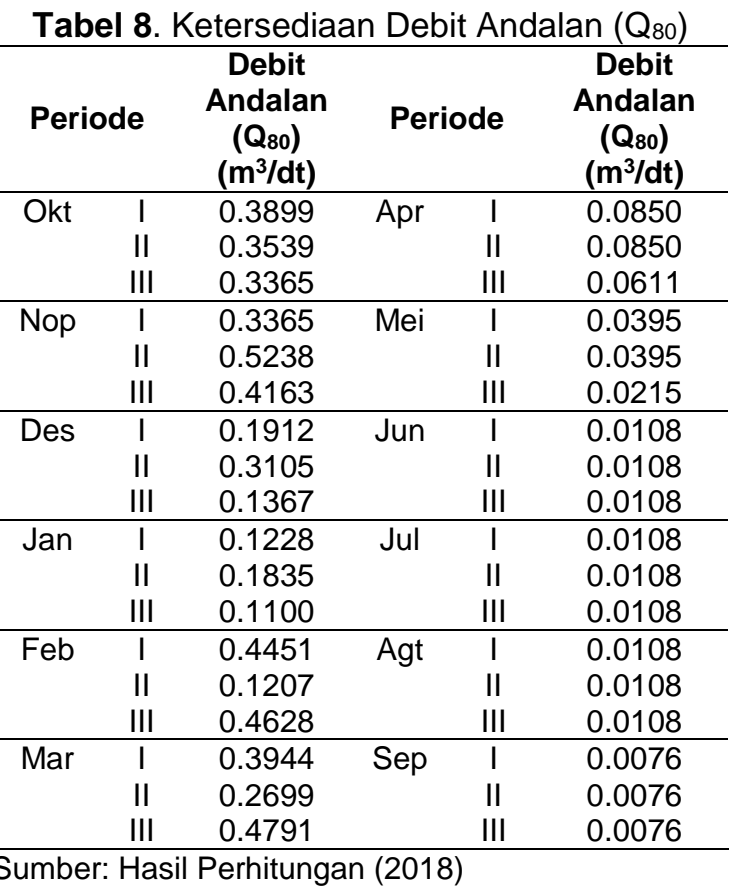

Ketersediaan air dari debit andalan tertinggi terjadi bulan Oktober hingga bulan Desember yang disebabkan oleh ketersediaan air yang melimpah pada musim hujan, sedangkan pada bulan juni hingga bulan sepetember debit andalan sangat rendah mencapai $0.0076 \mathrm{~m}^{3} / \mathrm{dt}$.

\section{Analisis Model Matematika}

Berdasarkan hasil survei Struktur Ongkos Usaha Tanaman Padi dan Palawija yang diselenggarakan oleh Badan Pusat Statistik (BPS) Propinsi Jawa Timur tahun 2016 (Padi) dan tahun 2017 (Palawija) yang meliputi kebutuhan biaya bibit, pupuk, pengendalian HPT, biaya tenaga kerja, sewa lahan, dan kebutuhan sarana/alat diperoleh keuntungan untuk pola tanam padi-padi-padi sebesar Rp. 13,500,000; pola tanam padi-padi-jagung+kacang tanah sebesar Rp. 13,626,000; dan pola tanam ubi kayu+kacang tanah-jagung-jagung sebesar Rp. 12,702,000; sehingga persamaan untuk mendapatkan keuntungan maksimum adalah sebagai berikut:

$$
\begin{gathered}
Z=13,500,000\left(X_{1}+X_{2}+X_{3}\right)+13,626,000\left(X_{4}+X_{5}+X_{6}\right) \\
+12,702,000\left(X_{7}+X_{8}+X_{9}\right)
\end{gathered}
$$

Fungsi kendala dalam penelitian ini adalah ketersediaan air (periode 10 harian) dan keterbatasan lahan sebesar $21.61 \mathrm{Ha}$, sehingga fungsi kendala luas tanam dan kendala debit air dirumuskan dalam penelitian ini.

Kendala Luas Tanam:

\section{Hasil Optimasi}

$$
X_{1}+X_{2}+X_{3}+X_{4}+X_{5}+X_{6}+X_{7}+X_{8}+X_{9}+X_{10}+X_{11}+X_{12} \leq 21.61
$$

Hasil optimasi Pola Tanam ditunjukkan oleh Tabel 10. 


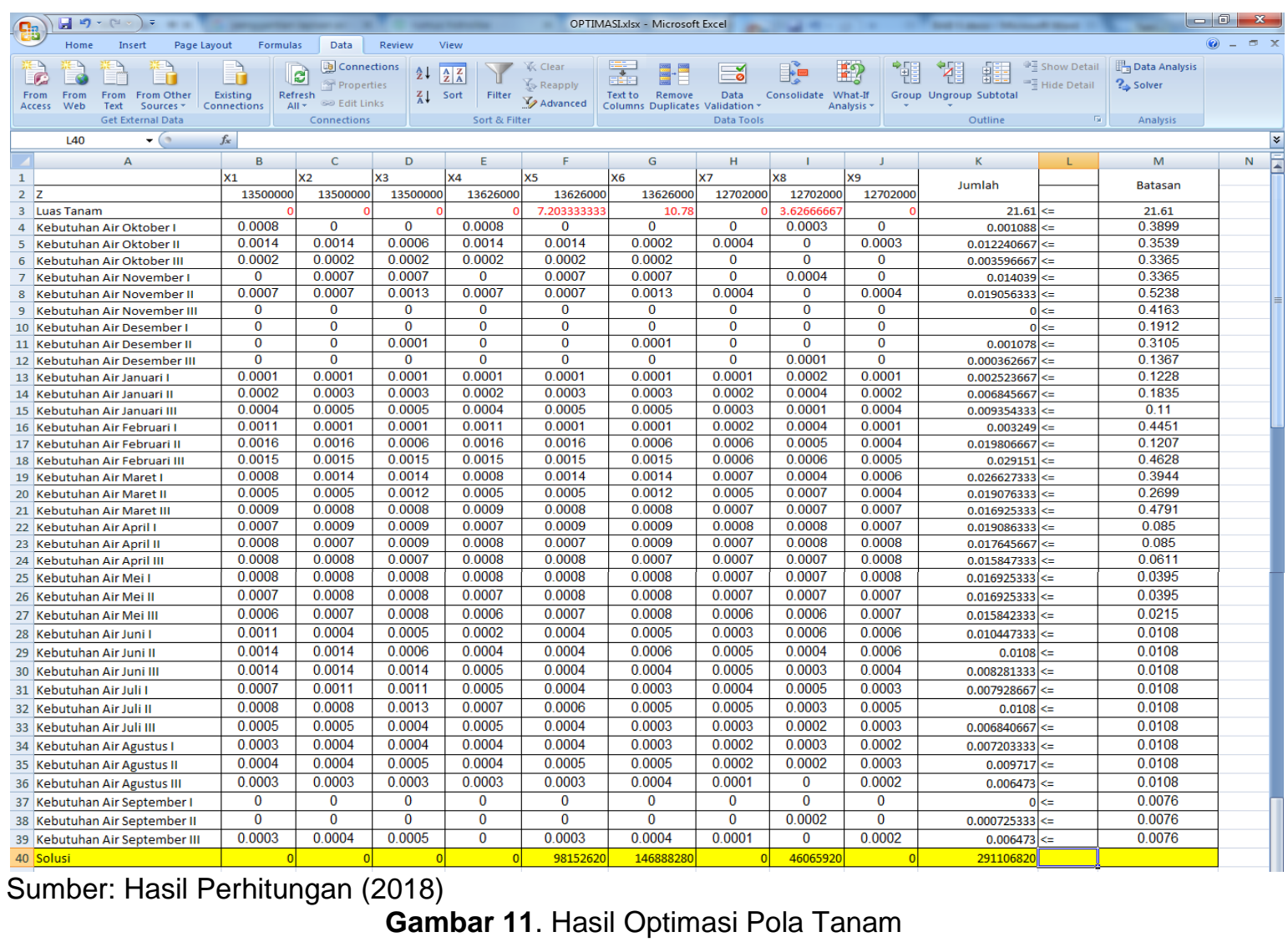

Gambar 11 menunjukkan bahwa total lahan sawah yang tersedia $(21,61 \mathrm{Ha})$ dapat dimanfaatkan secara maksimal melalui 3 alternatif pola tanam, yaitu X5, X6, dan X8. Pola Tanam X5 adalah sebesar 7.203 Ha. Ketersediaan air pada Musim Kemarau (MK) II menyebabkan kurang optimalnya tanaman padi untuk dibudidayakan di DI Kajar 2C. Keuntungan maksimal yang diperoleh dari pola tanam ini adalah sebesar Rp. 98,152,620; Pola tanam X6 sebesar $10.78 \mathrm{Ha}$ memberikan keuntungan maksimal sebesar Rp. 146,888,280. Awal tanam Oktober III dapat memnimalisasi kebutuhan air pada MK II, sehingga luas tanam X6 lebih optimal dibandingkan X5. Luas tanam X8 sebesar $3.627 \mathrm{Ha}$ memberikan keuntungan maksimal sebesar Rp. 46,065,920. Tanaman ubi kayu dan kacang tanah menjadi alternatif untuk memaksimalkan luas tanam karena membutuhkan jumlah air yang lebih sedikit dibandingkan padi. Pola tanam monokultur padi/padi/padi tidak disarankan berdasarkan hasil optimasi. Ketersediaan air pada MK I dan MK II menjadi penyebab utama tidak dianjurkannya baik untuk X1, X2, maupun X3.

\section{Kesimpulan}

Berdasarkan hasil optimasi dapat disimpulkan bahwa luas lahan total $21.61 \mathrm{Ha}$ dapat dimaksimalkan dengan menerapkan pola tanam X5 seluas $7.203 \mathrm{Ha}$, pola tanam X6 
seluas $10.78 \mathrm{Ha}$, dan luas tanam X8 seluas $3.627 \mathrm{Ha}$. Keuntungan maksimal yang dapat diperoleh adalah Rp. 146.888.280.

\section{Daftar Pustaka}

Dinas Pekerjaan Umum dan Perumahan Rakyat. 2013. Data Irigasi Kota Malang

Harisuseno, D. dan M. Bisri. 2017. Limpaan Permukaan secara Keruangan (Spatial Runoff). UB Press. Malang

Mauidzotussyarifah, N. Aini, dan N. Herlina. 2018. Optimalisasi Pemanfaatan Lahan dengan Pola Tanam Tumpangsari pada Tanaman Buncis (Phaseolus vulgaris L.) dan Tanaman Pakcoy (Brassica rapachinensis). Jurnal Produksi Tanaman 6(2): 246 $-251$

Mochammad, T. L., A. Nadjaji, dan Edijatno. 2013. Studi Optimasi Pola Tanam pada Daerah Irigasi Konto Surabaya dengan Menggunakan Program Linear. Jurnal Teknik Pomits 2(1): $1-6$

Septyana D., D. Harlan, dan Winskayati. 2016. Model Optimasi Pola Tanam untuk Meningkatkan Keuntungan Hasil Pertanian dengan Program Linier (Studi Kasus Daerah Irigasi Rambut Kabupaten Tegal Provinsi Jawa Tengah). Jurnal Teknik Sipil 23(2): $145-155$

Wirosoedarmo, R. 2010. Drainase Pertanian. UB Press. Malang 